\title{
BREEDING PASSION FRUIT POPULATIONS - REVIEW AND PERSPECTIVES
}

\author{
Rodrigo Moreira Ribeiro ${ }^{1}$, Alexandre Pio Viana ${ }^{2}$, Eileen Azevedo Santos 3 , \\ Daniele Lima Rodrigues ${ }^{1}$, Sandra da Costa Preisigke ${ }^{1}$
}

\begin{abstract}
${ }^{l}$ Engenheiro Agrônomo. Pós-doutorando do programa de genética e melhoramento de plantas da UENF.
${ }^{2}$ Engenheiro Agrônomo. Professor Associado da UENF.

${ }^{3}$ Bióloga. Pós-doutorandado programa de genética e melhoramento de plantas da UENF.
\end{abstract}

Corresponding author: Rodrigo Moreira Ribeiro (ribeirouenf@gmail.com).

\begin{abstract}
Passion fruit tree belongs to the family Passifloraceae. The genus Passiflora is considered of great economic value, and the main species cultivated is Passiflora edulis Sims. Brazil is the largest world producer of passion fruit, with annual production of around 823 thousand tons. In order to meet the demand for fruits from both domestic and international markets, as well as from the fresh consumption market and industry, the genetic breeding of this species has proved to be the major connection between farmers and the consumer market. Therefore, the Universidade Estadual do Norte Fluminense Darcy Ribeiro has been developing a passion fruit breeding program since 2002 and has recently launched a new variety - UENF Rio Dourado - which is already available to farmers. Aiming to overcome all obstacles for cultivation, the passion fruit genetic breeding program carried out by the UENF seeks to obtain the genetic progress of the crop and provide new cultivars even more productive and more resistant to the main pathogens of this species. Thus, this work aims to carry out a survey on the breeding of the crop and report future prospects made possible by the introduction of new techniques into the sour passion fruit breeding program.
\end{abstract}

Keywords: Passiflora edulis Sims., Recurrent Selection, Breeding, Targeting Resistance

\section{Introduction}

Passion fruit tree belongs to the family Passifloraceae. The genus Passiflora is considered of great economic value, whose main cultivated species is Passiflora edulis Sims, popularly known as sour passion fruit (Bernacci et al., 2008). It is cultivated in nearly $90 \%$ of the Brazilian orchards, mainly due to its quality, productivity, vigor and juice yield (Ferreira et al., 2016, Viana et al., 2016). Its economic potential is associated to the rapid capital return, the preference of the domestic and foreign markets due to its pleasant aroma, sugar content, vitamins $\mathrm{A}$ and $\mathrm{C}$, and mineral composition, which are the reason of its high quality juice (Falconner et al., 1998). The passion fruit tree is native to tropical America. It is considered a rustic plant, whose cycle ranges from 12 to 36 months (Araújo et al., 2016). The crop is in rapid expansion for the production of fruits for both fresh consumption and the juice industry (Faleiro et al., 2011).

Brazil is an international reference in sour passion fruit production and consumption. It is the largest world producer and generates around 695 thousand tons (IBGE, 2015). Considering the economic and social value of the cultivation of this fruit tree and seeking to maintain its competitiveness in the market, Brazil must improve genetic breeding research for the fast achievement of new cultivars (Ferreira et al., 2016, Viana et al., 2016) and overcome thef low-availability of commercial passion fruit cultivars. Today, there are 28 cultivars available to farmers in the seed market (Krause et al., 2012; MAPA, 2018).

Therefore, passion fruit breeding is focused on three main aspects of the fruit: meeting the market demands for quality, increasing crop yield of tillage and developing cultivars resistant to diseases (Gonçalves et al., 2009; Viana et al., 2016).

With such vision, the UniversidadeEstadual do Norte Fluminense Darcy Ribeiro (UENF) has been developing a breeding program for the species since 1998, which started with the initial collection of several genotypes from three producing regions in the state of Rio de Janeiro (Viana et al., 2003; Viana et al., 2016). This resulted in the launching, in 2016, of the cultivar UENF Rio Dourado, which is already available to farmers. 
Therefore, the present work aimed to carry out a review on the genetic breeding of sour passion fruit and the prospects for its future use.

\section{CHARACTERIZATION OF PASSION FRUIT SPECIES AND CULTIVATION}

As for its growth behavior, passion fruit plant is climbing, semilenous, fast growing, with early fruiting, and can reach 5 to $10 \mathrm{~m}$ in length (Ruggiero et al., 1996). The root system can be pivotal or axial, with its greatest concentration at the depth between 0 and $45 \mathrm{~cm}$ from the soil (Manica, 1997). The passion fruit tree presents simple and alternating leaves, with varied forms, well developed foliaceous bracts at its base and tendrils that fix the plant on supports (Manica, 1997). It is a perennial plant, but lasts between one and six years in commercial orchards (Martins et al., 2006).

The occurrence of diseases is one of the main factors that limit the expansion of areas cultivated with passion fruit tree (Freitas et al., 2016a). Diseases in the root system and aerial part of the plant are common. Such diseases cause early death, defoliation, delayed fruit maturation, occurrence of fruits with low pulp yield and consequently decreased quality and productivity, which leads to many economic and social losses (Cerqueira-Silva et al., 2014; Preisigke et al., 2015; Santos et al., 2015). The passion fruit tree can be attacked by several fungi, viruses and bacteria, which cause some diseases, including tipping, damping off, anthracnose, scab, bacteriosis, septoria blotch and woodiness. Among the major diseases that cause serious damage to the crop, we highlight bacteriosis (Xanthomonas axonopodis pv. passiflorae) and passion fruit woodiness disease (Cowpea aphid-borne mosaic virus - CABMV) (Cerqueira-Silva et al., 2014; Freitas et al., 2016b). According to Cerqueira-Silva et al. (2014), the curative control of diseases is expensive and often uses unfeasible cultural treatments. Therefore, the achievement of potentially resistant and productive cultivars via genetic breeding is the main strategy to overcome this problem.

Besides, high production can only be reached by using improved cultural practices associated to the planting of improved varieties. A superior variety cannot present all its production capacity on a poor and ill-prepared soil. On the other hand, high yields will not be achieved in well prepared and fertilized soils if the seeds used for planting come from inferior plants, with low production capacity or susceptible to diseases (Vieira, 1964). Therefore, breeding programs should not be limited to produce new elite varieties adapted to the different producing regions, given that plants will only demonstrate their high productive potential if all their nutritional needs and management practices are provided.
Regarding the fruit, the desired traits vary according to the purpose intended. In terms of quality, a variety developed for the fresh market should present large and oval fruits, with internal cavity completely filled, so as to be well rated in the market and resistant to losses in quality during transportation, storage and commercialization. However, if the production is focused on industry, fruit should present a thin shell, completely filled internal cavity, high juice yield, pulp with stable yellow-gold color and high content of soluble solids, above $13^{\circ}$ Brix (Abreu et al., 2009; Cavichioli et al., 2011).

Thus, passion fruit breeding is focused on three main pillars: achievement of high yields, resistance to diseases and fruits for fresh consumption industry.

\section{GENETICS APPLIED TO PASSION FRUIT POPULATIONS}

\section{UENF Sour Passion Fruit Breeding Program: from the beginning to the launching of the cultivar 'UENF Rio Dourado'}

The sour passion fruit breeding program developed by the UniversidadeEstadual do Norte Fluminense Darcy Ribeiro, synthetized in Table 1, started in 1998, with the collection of several genotypes from three producing regions in the state of Rio de Janeiro (Viana et al., 2003). Based on these early studies, a broader sampling was carried out in commercial areas in the Northern Rio de Janeiro.

In 2002, a large number of progenies was obtained from the base population by using Design I, proposed by Comstock and Robinson (1948). Thus, based on the results of these previous analyses, an intrapopulation recurrent selection program was prepared. In 2004, 113 full-sib families were assessed and the best $30 \%$ of the families were selected. These superior families were recombined and 26 half-sib families were obtained in 2006, when the first cycle of recurrent selection (Silva et al., 2009) was concluded. In 2007, the 26 half-sib families were evaluated. Then, 140 full-sib families were obtained. Next, the 140 full-sib families were evaluated and the top $30 \%$ of the families were selected by selection index, a step concluded in 2008. In 2009, the superior families were recombined, thus ending the second cycle of recurrent selection (Ferreira et al., 2016). Soon afterwards, in 2011, 28 half-sib families were evaluated, from which full-sib families were obtained. Between 2012 and 2015, 81 full-sib families were evaluated and the top $30 \%$ of the families were selected and recombined, and the third selection cycle (Viana et al., 2016; Silva et al., 2017) was concluded.

The experiments were arranged in a randomized block design with two replicates and five plants per plot. The management of weeds, pests, diseases and fertilization was carried out according to the procedures 
recommended for the crop. Irrigation was performed daily during the dry season. The 22 best progenies were selected for their fruit traits via BLUP (best linear unbiased prediction). The selected progenies were planted in field in the municipalities of Campos dos Goytacazes and Itaocara, Rio de Janeiro. The seeds of the fruits resulting from open pollination originated the cultivar UENF Rio Dourado (Viana et al., 2016).

\section{Mixed Models approach in passion fruit genetic breeding}

The passion fruit genetic breeding program aims to meet the requirements of the consumer market, especially regarding fruit quality (Viana and Gonçalves, 2005). Success in breeding programs in meeting these demands depends on the selection of the best individuals, in other words, the parents of the following generations. This relationship between the efficiency in the selection of the best individuals and success is even more noticeable in the perennial and semiperennial species with long reproductive cycles and expressions of different traits due to possible changes in controlling genes throughout several ages (Ferreira et al., 2016). Thus, it is necessary to use methods that allow the prediction of the genetic value of the individual through its phenotypic traits.

However, successful selection depends not only on the variability of the experimental material, but also the accuracy of the selection methods employed (Santos et al., 2015). Therefore, the REML/BLUP mixed models methodology has proved to be a great alternative to help the selection process. This methodology involves the estimation of the variance components by the Restricted Maximum Likelihood (REML) method and the prediction of the genotypic values by the Best Linear Unbiased Prediction (BLUP). This results in a more accurate selection process (Resende, 2002; Alves and Resende, 2008).

In perennial species, which coexist with conditions of imbalance of experimental information, it is possible to apply the mixed models, since they do not require balancing. Besides, they correct the data for the environmental effects and can predict the genetic values, with accuracy and free from bias, which maximizes the genetic gain with selection (Resende, 2002). This procedure has been applied in several crops, especially perennial and fruit crops, such as coffee (Carias et al., 2016), rubber tree (Kalil et al., 2000), eucalyptus (Rocha et al., 2006), cupuaçu (Alves e Resende, 2008), açaí (Teixeira et al., 2012), sugarcane (Lopes et al., 2014), guava (Gomes et al., 2017) and papaya (Vivas et al., 2014).

The REML/BLUP methodology has been successfully used in sour passion fruit breeding programs for advances in the recurrent selection cycle (Ferreira et al., 2016; Silva et al., 2016, Silva et al.,
2017), for the early selection of superior plants in the intrapopulational breeding of sour passion fruit (Cavalcante et al., 2017), in the advancement of generations in breeding programs aimed at genetic resistance to CABMV (Santos et al., 2015; Freitas et al., 2016b). It also provides the best predicted genetic gains compared to those obtained by selection indexes and is efficient in the selection of sour passion fruit progenies (Silva et al., 2017).

\section{Inheritance standard of the main traits}

The genetic breeding of passion fruit tree in Brazil has huge potential to increase the availability of cultivars with higher production and fruit quality and reduce production costs so as to guarantee increased competitiveness and profitability for farmers.

The availability of passion fruit cultivars with good agronomic traits, high fruit quality and genetic resistance to the main diseases is a great challenge for crop breeders, since these traits have not been found in a single genotype. Knowledge on the genetic variability of this species is of the utmost importance for the indication of potential parents and the combination of alleles related to traits of economic relevance in the management of crosses in breeding programs (Dias et al., 2011).

High phenotypic variation has been reported in literature (Nascimento et al., 2003; Negreiros et al., 2008) for morphological and agronomic traits, such as pulp mass, fruit mass, bark mass, soluble solids content, bark thickness, fruit length and diameter. It has also been observed very low genetic variability in resistance to disease in commercial cultivars (Cerqueira-Silva et al., 2008). Therefore, understanding the nature and intensity of variations of genetic and environmental origin is fundamental for the effectiveness of breeding procedures. The breeding of the agronomic traits of interest depends on the basic knowledge about the inheritance of the traits, the genetic variability available for breeding and the estimates of the genetic parameters (Dias et al., 2011).

However, production systems are based on the cultivation of a few varieties, which limits genetic variability. This practice may increase vulnerability to diseases and pests and compromise the sustainability of this crop (Dias et al., 2011). In their study, Viana et al. (2003) observed low genetic variability while testing different accessions of sour $P$. edulis. This reveals that the genetic base among the commercial cultivars may be narrowing. Thus, the search for increased genetic variability through the development of new genotypes may increase the competitiveness and sustainability of the crop (Dias et al., 2011).

Therefore, according to Faleiro et al., (2006), knowledge about the genetic basis of agronomic traits is essential for the breeding program. Estimates of genetic 
parameters, correlations and genetic inheritance of the traits are fundamental for establishing the best breeding strategies. The main demands are related to the study on the inheritance of resistance to diseases and the physical and chemical traits of fruits.

Using this approach, Gonçalves et al., (2009) obtained progenies through crosses between sour passion fruit cultivars (Passiflora edulis L.), following the Design I of Comstock \& Robinson (1948), in order to estimate the genetic parameters. The analysis of variance revealed great variability to be explored in the studied population. These authors concluded that the trait average number of fruits expressed the highest coefficient of additive genetic variation. It demonstrates that higher gains can be obtained for the trait. As regards the gene activity of the traits number of fruits per plant, bark thickness and number of days for flowering, this work has demonstrated that it is due to the superdominant effect of the genes. Other important traits present additive effect greater than the dominant effect, as observed in the weight, length and width of fruits. The highest values for heritability coefficients were obtained for families of males, and the lowest values, for families of females within males. For the purposes of selection, the narrow-sense coefficients should be used.

Among fruit diseases, passion fruit woodiness disease- CABMV - is the most prominent. The disease is caused by an aphid that transmits the virus that causes the disease to the passion fruit plant when it performs the test bite. The satisfactory control of the disease is difficult to achieve, since the transmitting agent visits the passion fruit tree only to feed, and does not remain on the plants. Thus, control via insecticides is inefficient, since the type of virus-vector relationship is non-persistent. In passion fruit plants infected by CABMV, the main symptoms observed are mosaic, leaf deformation, bubbles and thickening and hardening of the fruit pericarp.

Freitas et al. (2015) investigated inheritance for resistance to $\mathrm{CABMV}$ in a population resulting from an interspecific cross-breeding and rejected the monogenic inheritance. They confirmed that gains may be obtained through selection, provided that it deals with large populations and that more complex breeding methods are used, such as as recurrent selection.

The traits indirectly or directly related to productivity generally result from polygenic inheritance and may be strongly affected by the environment in the expression of the phenotype. In this case, the use of recurrent selection has proved to be an excellent breeding strategy, with evident genetic gains for the traits of interest through the gradual increase in the frequency of favorable alleles in the population (Viana et al., 2016; Ferreira et al. al., 2016).

\section{PASSION FRUIT GENETIC BREEDING}

\section{Recurrent Selection}

The sour passion fruit breeding programs aim to improve the morphological, physiological and agronomic traits and increase fruit productivity and quality, while searching for genotypes resistant or tolerant to important pests and diseases, with greater production stability (Gonçalves et al., 2007, Pimentel et al., 2008, Santos et al., 2010, Santos et al., 2011; Rosado et al., 2012).

Thus, some breeding methods are applicable to passion fruit, aiming to increase the frequency of favorable alleles or the exploitation of the hybrid vigor (Meletti et al., 2000; Rosado et al., 2012). Therefore, it is possible to obtain populations with several improved traits of interest and preserve the allelic variability at self-incompatibility loci (Suassuna et al., 2003; Rosado et al., 2012).

Among the breeding methods, recurrent selection is a system designed to gradually increase the frequency of alleles favorable for a quantitative trait, by means of repeated selection cycles, without losses in the population genetic variability (Hallauer, 1992). Recurrent selection is conducted in three stages: development, evaluation and recombination of progenies. These steps are carried out cyclically until satisfactory levels of favorable allele frequency are reached in the population (Hull, 1945; Hallauer et al., 2010).

In the conduction of the first cycle of the recurrent selection of the sour passion fruit population UENF Rio Dourado, Silva et al. (2009) evaluated 26 progenies of half-sibs obtained from the recombination of the progenies selected by Gonçalves et al. (2009), while conducting the Design I of Comstock \& Robinson (1948). These authors concluded that the selection strategy at the progeny generation stage provided genetic gains. The estimates of the genetic parameters and correlations obtained, as well as the genetic gains observed, allowed for the selection of superior progenies of passion fruit. Thus, the predicted genetic gains were significant and contributed to the selection process.

Ferreira et al. (2016) continued the breeding program and implemented the second selection cycle in the UENF Rio Dourado population, and assessed 27 half-sib progenies that resulted from the recombination of $30 \%$ of the best progenies out of the 140 full-sib progenies selected via selection index. The superior families were selected based on the REML / BLUP methodology, and the model presented was adequate for assessing sour passion fruit. The authors concluded that the estimates of the genetic and phenotypic parameters revealed that success could be achieved with the selection of superior progenies for the continuation of the breeding program. 
The third recurrent selection cycle, in turn, was conducted by Silva et al. (2014), who assessed 81 fullsib families. The present work aimed to quantify the genetic diversity between progenies of sour passion fruit, in order to define possible heterotrophic groups, based on morpho-agronomic descriptors, through the Ward-MLM procedure, thus favoring the generation advancement in the sour passion fruit genetic breeding program. This work concluded that there is genetic variability among the passion fruit progenies studied, which allows the composition of heterotic groups as an alternative for defining new crosses and obtaining genetic advance. The Ward-MLM statistical procedure was useful for detecting genetic divergence and grouping the accessions by using quantitative and qualitative variables. Therefore, this study provided useful information for determining the conductance of the ongoing passion fruit breeding program.

Today, the sour passion fruit intrapopulation breeding is at the fourth cycle of recurrent selection, aiming to continue the breeding process of the work population and continue using modern techniques to assess the progenies under study and estimate the genetic parameters for the traits (Silva et al., 2014). The results obtained in this study were similar to those reported by Silva et al. (2014).

\section{Breeding aiming at resistance to disease}

The passion fruit genetic breeding aims to increase productivity, fruit quality, fruit set rate, and resistance to diseases. Regarding resistance, the crop presents another hindrance, which is its short longevity. In several areas used for sour passion fruit crops planted at the end of the last century, crops aged 6 to 8 years were observed in full production. However, in recent years, the crops planted in the same areas have not exceeded two years of age. In many cases, total death occurs at the early age of one year. This is due to phytosanitary problems leading to a drop in production and significant decrease in the duration of plantations. In some areas, this problem even prevented cultivation (Paula et al., 2010; Freitas et al., 2015, Freitas et al., 2016a).

The main diseases in passion fruit include the fruit hardening virus caused by Cowpea aphid-borne mosaic virus (CABMV, genus Potyvirus, family Potyviridae) (Monteiro-Hara et al., 2011; Oliveira et al., 2013; Santos et al., 2015; Freitas et al., 2015) and stem rot, caused by Nectria haematococca Berk\& Br. [F. anamorphic: Fusarium solani (Mart.) Sacc.], which kills young plants (Fischer et al., 2010; Freitas et al., 2016a).

Some management recommendations were adopted to increase the economic viability of the crop and minimize the losses caused by the disease (Fischer et al., 2007; Sampaio et al., 2008). However, these procedures were not sufficient to reduce productivity losses. Then, the use of resistant varieties emerged as an alternative (Junqueira et al., 2003, Junqueira et al., 2005; Freitas et al., 2015).

Therefore, the Universidade Estadualdo Norte Fluminense Darcy Ribeiro (UENF) develops a sour passion fruit breeding program targeting resistance to diseases, and have achieved some results (Table 2).

Santos et al. (2015) evaluated resistance to CABMV in 178 genotypes of Passiflora constituted of interspecific hybrids and their parents (P. edulis $\mathrm{x} P$. setacea), and estimated genetic parameters for the area under the disease progress curve (AUDPC), to obtain passion fruit cultivars resistant to CABMV. The results obtained by these authors provide some prospects for possible CABMV control (by genetic resistance) in passion fruit plant. The results suggested that resistant hybrid plants can be selected and recombined with $P$. edulis genotypes and reassessed to corroborate their resistance to $\mathrm{CABMV}$, in such a way to continue the breeding program targeting to obtain genotypes resistant to CABMV for the cultivated areas.

Freitas et al. (2015) evaluated 369 genotypes, including the parents $P$. edulis (susceptible), $P$. setacea (resistant), the hybrids (P. edulis $x$ P. setacea) and $\mathrm{RC}_{1}$, in order to identify resistant genotypes in populations of passion fruit obtained by backcrossing and study resistance inheritance. These authors concluded that the inheritance for resistance is polygenic, and that there is gain in selection, provided that it uses large populations and more complex methods, such as backcrossing and recurrent selection.

Another study developed by Freitas et al. (2016a) aimed to obtain progenies through interspecific crosses between Passiflora edulis and Passiflora mucronata, perform the morpho-agronomic assessment of the progenies obtained and evaluate and select genotypes resistant to Fusarium solani. They verified that the genotypes studied formed six groups. Resistance to fungi was detected in the genotypes of $P$. mucronata, from Bahia, and in two hybrids. The authors concluded that the resistant hybrid could be backcrossed with $P$. edulisand / or used as a rootstock for sour passion fruit.

The study conducted by Freitas et al. (2016b) aimed to assess the interspecific hybrids from the parentsP. setaceaand P. edulisfor the morphoagronomic traits related to CABMV, according to the severity of the symptoms and serological tests. The authors estimated the genetic parameters and obtained the prediction of the genetic gains. Five quantitative fruits traits were evaluated in 77 individuals during two growing seasons, using the REML / BLUP methodology. The genotypes H5-1, H9-11, H9-57 and H2-20 stood out at harvest times as the best individuals for number of fruits, yield and pulp mass, which demonstrates that they are the most suitable to be used as parents in backcrossing with sour passion fruit. 
Therefore, the selection of sour passion fruit cultivars with high yield and fruit quality besides resistance to the most important plant pathogens is fundamental for the development and progressof the crop in the main producing regions of our country and the world.

\section{FUTURE PROSPECTS}

\section{Marker-Assisted Selection}

DNA markers were first used in plant breeding in the early 1980s (Soller and Beckmann, 1983). Briefly, they are segments of DNA physically attached to loci that determine traits of interest. They can be evidenced by methods that combine the use of restriction enzymes to hybridization between DNA complementary sequences, including the "Restriction Fragment Length Polymorphisms" (RFLP), by Polymerase Chain Reaction (PCR) technique or by the detection of polymorphisms resulting from changes in a single genomic base, such as in the "Single nucleotide polymorphisms" (SNP) technique. Alzate-Marin et al. (2005) claim that the great potential for using molecular markers in breeding programs lies in the fact that they are almost unlimited in number, easy to detect, and behave as "traits" of simple and predictable inheritance, unaffected by the environment.

The PCR technique resulted in great advances. The refinement of the techniques gave rise to new markers, which can be sorted into dominant and codominant. The dominant markers include: RAPD (Random Amplified Polymorphic DNA) (Williams et al., 1990), AFLP (Amplified Fragment Length Polymorphism) (Vos et al., 1995), ISSR (intersimple sequence repeats) (Zietkiewicz et al., 1994) and DarT (diversity array technology) (Kilian et al., 2005). The codominant markers include: SSR (Simple Sequence Repeats) (Tautz, 1989) and SNPs (Single Nucleotide Polymorphism) (Chen and Sullivan, 2003). These different types of molecular markers also differ in their potential for detecting differences among individuals, their cost, the required facilities, and consistency and replication of results (Schlötterer, 2004; Schulman, 2007; Bernardo, 2008).

Advances in Molecular Biology and Genomics, mainly the development of DNA markers, have allowed studying and characterizing genetic variability at different levels. The development of genetic maps, for example, is one of the applications of greatest impact of the molecular technology. It allows finding the genes that control traits whose phenotypic expression depends on the action of a set of loci, or QTL (Carneiro and Vieira, 2002).

In the case of passion fruit, molecular markers have been used in studies on diversity (Cassiano et al., 1998; Viana et al., 2003; Ganga et al., 2004), genetic variability (Viana et al., 2003; Crochemore et al.; 2003; Faleiro et al., 2007; Bellon et al., 2014) and map construction (Carneiro et al.; 2002; Lopes et al., 2006).

\section{Genome Selection}

Genome wide selection - GWS or genome selection - GS was proposed by Meuwissen et al. (2001) as an alternative to increase efficiency and accelerate genetic breeding. GWS emphasizes the simultaneous prediction (without using significance tests for individual marks) of the genetic effects of large numbers of DNA genetic markers (SNP, DArT, Microsatellites) dispersed throughout the genome of an organism in order to capture the effects of all loci (of small and great effects) and explain all the genetic variation of a quantitative trait. The fundamental condition for this is the occurrence of imbalance of linkage between alleles of the markers and alleles of the genes that control the trait. Prediction is performed based on genotypic and phenotypic data from individuals belonging to a sample of the selection population.

In order to verify the possible implementation of GWS in the UENF passion fruit genetic breeding program, 250 microsatellite markers were simulated and evaluated, by means of a procedure implemented through the use of databases available for the species and the "multiple imputation" technique via the R program (Broman and Sen, 2009) in 140 full-sib progenies of yellow passion fruit from the intrapopulation recurrent selection program in the second selection cycle of the UENF, which were phenotyped for the variable total number of fruits per plant (Viana et al., 2017).

The analyses were carried out using the randomized regression method (RR-BLUP / GWS), which employs BLUP predictors, with the effects of markers not adjusted as classificatory variables, but as explicative or explanatory variables (Viana et al., 2012).

Genomic genetic values (GGV) were initially counted using all markers. Then, the markers were ordered considering the greater modules of the estimated effects of the markers, and files were created with subsets of markers with larger estimated effect modules (1 to 250). All of these files were analyzed for computing the effects of the marker loci on the estimation and validation populations to verify the effects of these loci on the explanation of all the existing variation for the trait under study. It was verified that the heritability rate that maximizes the predictive capacity in the cross validation was 0.85 . It was also verified that the predictive capacity and the accuracy were almost maximized in the analysis with 63 markers of greater effects. Predictive abilities decrease as the number of markers increase. The increased number of markers does not linearly increase GWS accuracy by the RRBLUP method. Therefore, it is expected that, following the genotyping of the study population, the broad 
genomic selection can be applied for the species under study, which would reduce the time for the generation of new varieties.

Thus, it is possible to conclude that the predicted genomic values presented high correlation with the phenotypic values predicted by the REML / BLUP technique. So, it is possible to foresee that the Amplified Genomic Selection application is viable for use in sour passion fruit genetic breeding programs (Viana et al., 2017).

\section{QTL Mapping}

In terms of molecular genetics, it is necessary to generate information on DNA content, genome size, isolation and cloning of the genes that control traits of agronomic interest, genetic mechanism leading to incompatibility and saturated binding maps to detect and locate QTL (Quantitative Trait Loci).

Advances in Molecular Biology and Genomics, especially the development of DNA markers, have allowed for the study and characterization of genetic variability at different levels. The development of genetic maps, for example, is one of most powerful applications of molecular marker technology, since it allows locating the genes that control traits whose phenotypic expression depends on the activity of a set of loci, or QTL (Carneiro and Vieira, 2002).

Genetic mapping is an important tool to be used in breeding programs, since one or more genotype marks may be associated with one or more genes controlling qualitative and quantitative traits (QTL) (Bhering et al., 2008). Undoubtedly, one of the most important applications of genetic maps is the mapping of QTLs, especially for the study of more complex traits. Its basic principle is the achievement of phenotypic data in a progeny and the identification of regions in the genome where the marker genotype can be associated with the phenotype of individuals (Broman and Sen, 2009).

Therefore, microsatellite markers are considered useful and very reliable for the construction of genetic maps and the mapping of QTLs in Passiflora populations. The use of molecular markers for the construction of genetic maps has already been reported for sour (P. edulis) and sweet (P. alata) passion fruit. For example, an $F_{1}$ population of passion fruit was genotyped with RAPD (Carneiro et al., 2002) and AFLP (Lopes et al., 2006), and an integrated map was generated by SSR and AFLPs (Oliveira et. al, 2008) and an integrated map of $P$. alata was prepared using new SSR markers, M-AFLP and SNP (Pereira et al., 2013).

In species with self-incompatibility and mandatory cross-breeding, which is the case of passion fruit, it is not possible to obtain conventional populations of mapping. Therefore, the pseudo-testcross technique is used to generate genetic maps, using a segregating $\mathrm{F}_{1}$ population and dominant marks, which results in the generation of individual maps, one per parent. The weakness of this strategy has been overcome by the use of codominant markers and more robust statistics. Markers based on SSRs (or microsatellites) and SNPs are useful to promote the integration of maps, since they are codominant and abundant in plant genome (Grattapaglia and Sederoff, 1994).

Crosses between susceptible and resistant species in perennial plants may originate mapping populations aiming at the genetic study of the number of alleles involved in these resistances, while forming breeding populations to obtain resistant genotypes. It is worth mentioning that the issue of self-incompatibility must be monitored in order to maintain allele diversity in the population of $P$. edulis enough to obtain good fructification in resistant genotypes. Studies on the identification of QTLs associated with fruit traits (Moraes et al., 2005) and resistance to Xanthomonas axonopopodis pv. passiflorae (Lopes et al., 2006) are reported in Passiflora. However, there are no reports of QTLs for resistance to CABMV in passion fruit.

\section{Proteomics}

Studies on the structure, function, and evolution of complete genomes, gene sequences and proteins resulting from gene expression should be considered as an important demand for research on passion fruit genetic breeding. There is still much to be known within the genus Passiflora and such analyses will allow the generation of a huge amount of data for the advancement of knowledge and understanding of the organization and physiological functioning of passion fruit.

Passion fruit is a culture widely exploited, but there is still little information on proteomic approaches using passion fruit tissues. The studies available are related to protein extraction methods (Perdizio et al., 2015), protein induction in response to herbivory (Jardim et al., 2010), and the detection of pathogeninduced proteins (Tahara et al., 2003).

A number of compounds that confer resistance to viruses, pathogenic bacteria and fungi have been identified in plants, including peptides and proteins with antimicrobial activity (Benko-Iseppon et al., 2010). The most known proteins involved in plant defense include protease inhibitors, lectins, pathogenesisrelated proteins, hydroxyproline-rich glycoproteins and Ribosome-inactivating proteins (Jamal et al., 2013). Enzymatic assays in passion fruit have shown the induction of Lipoxygenase activity (LOX), which occurred both locally and systematically in response to attacks from specialist and generalist insects (Jardim et al., 2010). Tahara et al. (2003) verified the expression of proteins induced by the bacterium Xanthomonas axonopodis pv. passiflorae in P. edulis. The authors detected a membrane protein and a hypothetical protein specifically induced by the passiflorae extract. 
To date, no studies have been carried out on protein detection associatedwith CABMV resistance in Passiflora. Further research on plant-virus interaction should consider the relevance of the proteins involved in the plant defense mechanism, as well as the detection and biochemical characterization of these molecules.

Table 1. Selection strategies used, main traits assessed and narrow-sense heritability for the trait number of fruits obtained for cycles $\mathrm{C}_{0}, \mathrm{C}_{1}, \mathrm{C}_{2}, \mathrm{C}_{3}$ and $\mathrm{C}_{4}$ in the UENF Rio Dourado population submitted to intrapopulation recurrent selection. Campos dos Goytacazes, 2018.

\begin{tabular}{cllcc}
\hline Cycle & Selection Strategies & \multicolumn{1}{c}{${\text { Main traits assessed }{ }^{2}}^{\text {Heritability }}$} & References \\
\hline C0 & Design $^{1}$ & NF, FW, FL, FWI, ST and NDF & 0.336 & Gonçalves et al. (2009) \\
C1 & Half-sibs & NF, FW, FL, FWI and ST & 0.369 & Silva et al. (2009) \\
C2 & Half-sibs & NF, Yldand FW & 0.395 & Ferreira et al. (2016) \\
C3 & Full-sibs & NF, Yld, FW, FWI, FL, PP, ST and SSC & 0.410 & Silva et al. (2016) \\
C4 & Full-sibs & NF, Yld, FW, FL, DF, ST, SSC and PH & 0.410 & Cavalcante et al. (2018) \\
\hline
\end{tabular}

${ }^{1}$ Design I of Comstock \& Robinson (1948)

${ }^{2} \mathrm{NF}$ - number of fruits per plant; FW - fruit weight, in grams; FL - fruit length in mm; FWI - fruit width in mm; ST - skin thickness in mm; NDF - number of days for flowering; Yld - yield; DF - Diameter of fruit; PP - percentage of pulp, ST -Skin thickness, SSC - soluble solids content; $\mathrm{PH}-\mathrm{pH}$

${ }^{3}$ Article accepted by the RevistaBrasileira de Fruticultura (Brazilian Journal of Fruits Crops).

Table 2. Generations advancement of passion fruit breeding program for resistance to Cowpea aphid-borne mosaic virus (CABMV) and agronomic performance. Universidade Estadual do Norte Fluminense Darcy Ribeiro.Campos dos Goytacazes, 2018.

\begin{tabular}{ccccc}
\hline Crossing & Population structure & Main traits assessed ${ }^{2}$ & $\begin{array}{c}\text { Heritabilityb } \\
\text { (DR) }\end{array}$ & References \\
\hline P. edulis x P. setacea & Interspecific hybrid (HI) $\begin{array}{l}\text { DR, NF, FM, TD, LD, ST, PM, LSS } \\
\text { and LA }\end{array}$ & 0.99 & Santos et al. (2015) \\
\hline HI5-14 x P.edulis & Backcrossing (BC, $)$ & DR,NF, FM, PM, SST and PRO & 0.94 & Freitas et al. (2015; 2016) \\
\hline HI ${ }^{1}$ x P. edulis & Backcrossing $\left(\mathrm{BC}_{1}\right)$ & $\begin{array}{l}\text { DR, NF, FM, TD, LD, LSS, PM, PRO } \\
\text { and SL }\end{array}$ & 0.90 & Preisigke (2017) \\
\hline
\end{tabular}

${ }^{1}$ Hybrids used in the crosses: HI5-14; HI1-15; HI5-16; HI5-1; HI2-10; HI5-13.

${ }^{2}$ DR- disease resistance (Area Under the Disease Progress Curve - AUDPC), NF-number of fruits per plant, FM-mean mass of the fruits, TDtransversal diameter of the fruit, LD- longitudinal diameter of the fruits, ST- shell thickness, PM- mean mass of the pulp, LSS- level of soluble solids, LA- length of the androgynophore, PRO- Productivity (average fruit weight multiplied by the number of fruits obtained), SL-seed length.

\section{Acknowledgements}

The authors are thankful to FAPERJ, CAPES and $\mathrm{CNPq}$ for their financial support and scholarship granting. 


\section{References}

ABREU, S.P.M.; PEIXOTO, J.R.; JUNQUEIRA, N.T.V.; SOUSA, M.A.F. 2009. Características físico-químicas de cinco genótipos de maracujazeiro-azedo cultivados no distrito federal. Revista Brasileira de Fruticultura, 31(2):487-491.

ALVES, R.; RESENDE, M.D.V. 2008. Avaliação genética de indivíduos e progênies de cupuaçuzeiro no Estado do Pará e estimativas de parâmetros genéticos. Revista Brasileira de Fruticultura, (3):696-701.

ALZATE-MARIN, A.L.; CERVIGNI, G.D.L.; MOREIRA, M.A.; BARROS, E.G. 2005. Seleção Assistida por Marcadores Moleculares Visando ao Desenvolvimento de Plantas Resistentes a Doenças, com Ênfase em Feijoeiro e Soja. Fitopatologia Brasileira, 30:333-342.

ARAUJO, M.M.V.; FERNANDES, D.Á.; CAMILI, E.C. 2016. Emergência e vigor de sementes de maracujá amarelo em função de diferentes disponibilidades hídricas. Uniciências, 20(2):82-87.

BELLON, G.; FALEIRO, F.G.; JUNQUEIRA, N.T.V.; FUHRMANN, E. 2014. Variabilidade genética de genótipos elite de maracujazeiro, obtidos em programas de retrocruzamento envolvendo espécies silvestres e comerciais com base em marcadores RAPD. Bioscience Journal, 30(6):1692-1697.

BENKO-ISEPPON, A.M.; GALDINO, S.L.; CALSA, J.R.T.; KIDO, E.A.; TOSSI, T.; BELARMINO, L.C.; CROVElla, S. 2010. Overview on Plant Antimicrobial Peptides. Current Protein Peptides Sciense, 11:181-188.

BERNACCI, L.C.; SOARES-SCOTT, M.D.; JUNQUEIRA, N.T.V.; PASSOS, I.R.D.S.; MELETTI, L.M.M. 2008. Revisão Passiflora edulis sims: the correct taxonomic way to cite the yellow passion fruit (and of others colors). Revista Brasileira de Fruticultura, 30(2):566-576.

BERNARDO, R.2008. Molecular markers and selection for complex traits in plants: learning from the last 20 years. Crop Science, 48:1649-1664.

BHERING, L.L.; CRUZ, C.D. 2008. Tamanho de população ideal para mapeamento genético em famílias de irmãos completos. Pesquisa Agropecuária Brasileira, 43:379-385.

BROMAN, K.W.; SEN, S.A.A. 2009. A Guide to QTL mapping with R/qtl, v.46. Springer, New York. 396p.

CARIAS, C.M.D.O.M., GRAVINA, G.A., FERRÃO, M.A.G., DA FONSECA, A.F.A., FERRÃO, R.G., VIVAS, M. 2016. Predição de ganhos genéticos via modelos mistos em Progênies de café conilon. Coffee Science, 11:39-45.

CARNEIRO, M.S.; CAMARGO, L.E.A.; COELHO, A.S.G.; VENCOVSKY, R.; LEITE JÚNIOR, R.P.; STENZEL, N.M.C.; VIEIRA, M.L.C. 2002. RAPD - based genetic linkage maps of yellow passion fruit (Passiflora edulis Sims f. flavicarpa Deg.). Genome, 45:670-678.

CARNEIRO, M.S.; VIEIRA, M.L.C. 2002. Mapas genéticos em plantas. Bragantia, 61(2):89-100.

CASSIANO, A.P.A.A.; LEMOS, E.G.M.; OLIVEIRA, J.C. 1998. Avaliação de espécies de Passiflora através de marcadores moleculares RAPD. Geneticsand Molecular Biology, 21(3):214.

CAVALCANTE, N.R; KRAUSE, W.; VIANA, A.P.; SILVA, C.A.; PORTO, K.K.X.; MARTINEZ, R.S. 2017. Anticipated selection for intrapopulation breeding of passion fruit. Acta Scientiarum.Agronomy, 39:143-148.

CAVICHIOLI, J.C.; CORRÊA, L.D.S.; BOLIANI, A.C.; SANTOS, P.C.DOS. 2011. Características físicas e químicas de frutos de maracujazeiro-amarelo enxertado em três. Revista Brasileira de Fruticultura, 33(3):906-914.

CERQUEIRA-SILVA, C.B.M.; CONCEIÇÃO, L.D.H.C.S.; SOUZA, A.P.; CORRÊA, R.X. 2014. A history of passion fruit woodiness disease with emphasis on the current situation in Brazil and prospects for Brazilian passion fruit cultivation. European Journal of Plant Pathology, 139(2):255-264. 
CERQUEIRA-SILVA, C.B.M.; MOREIRA, C.N.; FIGUEIRA, A.R.; CORREA, R.X. 2008. Detection of a resistance gradient to Passion fruit woodiness virus and selection of 'yellow' passion fruit plants under field conditions. Genetics and Molecular Research, 7:1209-1216.

CHEN, X.; SULLIVAN, P.F. 2003. Single nucleotide polymorphism genotyping: biochemistry, protocol, cost and throughput. The Pharmacogenomics Journal, 3:77-96.

COMSTOCK, R.E.; ROBINSON, H.F. 1948. The components of genetic variance in populations of biparental progenies and their use in estimating the average degree of dominance. Biometrics, 4:254-266.

CROCHEMORE, M.L.; MOLINARI, H.B.C.; VIEIRA, L.G.E. 2003. Genetic diversity in passion fruit (Passiflora spp.) evaluated by RAPD markers. Brazilian Archives of biology and Technology, 46(4):521-527.

DIAS, N.L.P.; OLIVEIRA, E.J.; DANTAS, J.L.L. 2011. Avaliação de genótipos de mamoeiro com uso de descritores agronômicos e estimação de parâmetros genéticos. Pesquisa Agropecuária Brasileira, 46 (11):1471-1479.

FALCONER, P.; TITTOTO, K.; PARENTE, T. V.; JUNQUEIRA, N. T. V.; MANICA, I. 1998. Caracterização físico-química de frutos de seis cultivares de maracujá-azedo (Passiflora spp) produzidos do Distrito Federal. In: Simpósio Brasileiro Sobre a Cultura do Maracujazeiro, Funep, Jaboticabal. p.257-79.

FALEIRO, F. 2007. Marcadores moleculares aplicados a programas de conservação e uso de recursos genéticos, Embrapa Cerrados, Planaltina. 102p.

FALEIRO, F.G.; JUNQUEIRA, N.T.V.; BRAGA, M.F. 2006. Maracujá: demandas para a pesquisa. Embrapa Cerrados, Planaltina. 54p.

FALEIRO, F.G.; JUNQUEIRA, N.T.V.; BRAGA, M.F.; OLIVEIRA, E.J.; PEIXOTO, J.R., COSTA, A.M. 2011. Germoplasma e melhoramento genético do maracujazeiro: histórico e perspectivas, Embrapa, Planaltina. 36p.

FERREIRA, R.T.; VIANA, A.P.; SILVA, F.H.DEL.E.; ANTOS, E.A.; SANTOS, J.O. 2016. Seleção recorrente intrapopulacional em maracujazeiro-azedo via modelos mistos. Revista Brasileira de Fruticultura, 38(1):158-166.

FISCHER, I.H.; ALMEIDA, A.M.; FILETI, M.S.; BERTANI, R.M.A.; ARRUDA, M.C.; BUENO, C.J. 2010. Avaliação de passifloraceas, fungicidas e Trichoderma para o manejo da podridão-do-colo do maracujazeiro, causada por Nectria haematococca. Revista Brasileira de Fruticultura, 32(3):709717.

FISCHER, I.H.; ARRUDA, M.C.; ALMEIDA, A.M.; GARCIA, M.J.M.; JERONIMO, E.M.; PINOTTI, R.N.; BERTANI, R.M.A. 2007. Doenças e características físicas e químicas pós-colheita em maracujá amarelo de cultivo convencional e orgânico no centro oeste paulista. Revista Brasileira de Fruticultura, 29(2):254-259.

FREITAS, J.C.O.; VIANA, A.P.; SANTOS, E.A.; PAINA, C.L.; SILVA, F.H.L. 2015. Genetic basis of the resistance of a passion fruit segregant population to Cowpea aphid-borne mosaic virus (CABMV). Tropical Plant Pathology, 40:291-297.

FREITAS, J.C.O.; VIANA, A.P.; SANTOS, E.A.; PAIVA, C.L.; SILVA, F.H.L.; AMARAL JÚNIOR, A.T, SOUZA, M.M.; DIAS, V. M. 2016a. Resistance to Fusarium solani and characterization of hybrids from the cross between P. mucronata and P. edulis. Euphytica, 208:493-507.

FREITAS, J.C.O.; VIANA, A.P.; SANTOS, E.A.; PAIVA, C.L.; SILVA, F.H.DEL.E.; SOUZA, M.M. 2016b. Sour passion fruit breeding: Strategy applied to individual selection in segregating population of Passiflora resistant to Cowpea aphid-born mosaic virus (CABMV). Scientia Horticulturae, 211:241-247.

GANGA, R.M.D.; RUGGIERO,C.; LEMOS, E.G.M.; GRILI, G.V.G.; GONÇALVES, M.M.; CHAGAS, E.A.; WICKERT, E. 2004. Diversidade genética em maracujazeiro- amarelo utilizando marcadores moleculares fAFLP. Revista Brasileira de Fruticultura, 26(3):494-498. 
GOMES, V.M.; RIBEIRO, R.M.; VIANA, A.P. 2017. Inheritance of resistance to Meloidogyne enterolobii and individual selection in segregating populations of Psidium spp. European Journal of Plant Pathology, 148:699-708.

GONÇALVES.M.G.; VIANA, A.P.; BEZERRA NETO, F.V.; PEREIRA, M.G.; PEREIRA, T.N.S. 2007. Seleção e herdabilidade na predição de ganhos genéticos em maracujá-amarelo. Pesquisa Agropecuária Brasileira, 42:193-198.

GONÇALVES, G.M.; VIANA, A.P.; PEREIRA, M.G.; FRANCISCO, NETO, V.B.; AMARAL JÚNIOR, A.T.; PEREIRA, T.N.S.; GONÇALVES, T.J.M. 2009. Genetic Parameter Estimates in Yellow Passion Fruit Based on Design I. Brazilian archives of biology and technology, 52(3):523-530.

GRATTAPAGLIA, D.; SEDEROFF, R. 1994. Genetic linkage maps of Eucalyptus grandis and Eucalyptus urophylla using a pseudo-testcross: Mapping strategy and RAPD markers. Genetics, 137:1121-1137.

HALLAUER, A. R. 1992. Recurrent selection in maize. Plant Breeding Reviews, 9:115-179.

HALLAUER, A.R.; CARENA, M.J.; MIRANDA FILHO, J.B. 2010. Quantitative genetics in maize breeding, 3rd ed. v.6. Springer, New York. 663p.

HULL, F.H. 1945. Recurrent selection and specific combining ability in corn. Journal of the American Societ of Agronomy, 37:134-145.

IBGE. 2015. Sistema IBGE de recuperação automática - Sidra. Produção agrícola municipal: produção de maracujá. Disponível em<http://www. sidra.ibge.gov.br/>. Acessado em 16 de fevereiro 2017.

JAMAL, F.; PANDEY, P.K.; SINGH, D.; KHAN, M.Y. 2013. Serine protease inhibitors in plants: nature's arsenal crafted for insect predators. Phytochemical Review, 12:1-34.

JARDIM, B.C.; PERDÏZIO, V.A.; BERBERT-MOLINA, M.A.; RODRIGUES, D.C.; BOTELHO-JÚNIOR, S.; VICENTE, A.C.; HANSEN, E.; OTSUKI, K.;URMËNYI, T.P.; JACINTO, T. 2010. Herbivore response in passion fruit (Passiflora edulis Sims) plants: induction of lipoxygenase activity in leaf tissue in response to generalist and specialist insect attack. Protein and Peptide Letters, 17(4):480484.

JUNQUEIRA, N.T.V.; ANJOS, J.R.N.; SILVA, A.P.O.; CHAVES, R.C.; GOMES, A.C. 2003. Reação às doenças e produtividade de onze cultivares de maracujá azedo cultivadas sem agrotóxicos. Pesquisa Agropecuária Brasileira, 38:1005-1010.

JUNQUEIRA, N.T.V.; BRAGA, M.F.; FALEIRO, F.G.; PEIXOTO, J.R.; BERNACCI, L.C. 2005. Potencial de espécie silvestre de maracujazeiro como fonte de resistência a doenças. In: Faleiro, F.G.; Junqueira, N.T.V.; Braga, M.F. (eds) Maracujá: Germoplasma e Melhoramento Genético, Embrapa Cerrado, Planaltina. p.81-106.

KALIL, F.A.N.; RESENDE, M.D.V.; KALIL, G.P.D.C. 2000. Variance components and prediction of genetic values in rubber tree clones by the mixed model methodology (REM/BLUP). Pesquisa Agropecuária Brasileira, 35(9):1883-1887.

KILIAN, A.; HUTTNER, E.; WENZL, P.; JACCOUD, D.; CARLING, J.; CAIG, V.; EVERS, M.; HELLERUSZYNSKA, K.; CAYLA, C.; PATARAPUWADOL, S.; XIA, L.; YANG, S.; THOMSON, B. 2005. The fast and the cheap: SNP and DArT-based whole genome profiling for cropimprovement. In: Tuberosa R, Phillips RL, Gale M (eds) Proceedings of the international congress "In the wake ofthe double helix: from the green revolution to the generevolution". University of Bologna, Bologna. p.443-461.

KRAUSE, W.; SOUZA, R.S.; NEVES, L.G.; CARVALHO, M.L.S.; VIANA, A.P.; FALEIRO, F.G. 2012. Ganho de seleção no melhoramento genético intrapopulacional do maracujazeiro amarelo. Pesquisa Agropecuária Brasileira, 47(1):51-57. 
LOPES, R.; TERESA, M.; LOPES, G. 2006. Linkage and mapping of resistance genes to Xanthomonas axonopodis pv. passiflorae in yellow passion fruit. Genome, 49:17-29.

LOPES, V.R.; BESPALHOK FILHO, J.C.; DAROS, E.; OLIVEIRA, R.A.; GUERRA, E.P. 2014. Divergência genética entre clones de cana-de-açúcar usando análise multivariada associada a modelos mistos. Semina: Ciências Agrárias, 35(1):125-134.

MANICA, I. 1997. Maracujá: Taxonomia - anatomia - morfologia: In. São José, A.L.; Bruckner, C.H.; Manica, I.; Hofmann, M. (Ed.). Maracujá: Temas selecionados - Melhoramento, morte prematura, polinização, taxonomia. Cinco Continentes, Porto Alegre. p.7-24.

MAPA. (2018) Ministério da Agricultura Pecuária e Abastecimento. Disponível em<http://extranet.agricultura. gov.br/php/snpc/cultivarweb/cultivares_registradas.php>. Acessado em 16 de fevereiro de 2018.

MARTINS, I.; PEIXOTO, J.R.; MELLO, S.C.M. 2006. Evolução do maracujazeiro-amarelo no Brasil, as principais doenças e possibilidade de aplicação do controle biológico. Embrapa Recursos Genéticos e Biotecnologia, Planaltina. 39p.

MELETTI, L.M.M.; SANTOS, R.R.; MINAMI, K. 2000. Melhoramento do maracujazeiro-amarelo: obtenção do composto IAC-27. Scientia Agrícola, 57:491-498.

MEUWISSEN, T.H.E.; GODDARD, M.E.; HAYES, B.J. 2001. Prediction of total genetic value using genomewide dense marker maps. Genetics, 157:1819-1829.

MONTEIRO-HARA, A.C.B.A.;JADÃO A.S.; MENDES, B.M.J.;REZENDE, J.A.M.;TREVISAN, F.; MELLO, A.P.O.A.; VIEIRA, M.L.C.;MELETTI, L.M.M.;PIEDADE, S.M.S. 2011. Genetic transformation of passionflower and evaluation of R1 and R2 generations for resistance to Cowpea aphid-borne mosaic virus. Plant Disease, 95:1021-1025.

MORAES, M.C.; GERALDI, I.O.; MATTA, F.P.; VIEIRA, M.L.C. 2005. Genetic and phenotypic parameter estimates for yield and fruit quality traits from a single wide cross in yellow passion fruit. HortScience, 40(7):1978-1981.

NASCIMENTO, W.M.O.; TOMÉ, A.T.; OLIVEIRA, M.S.P.; MÜLLER, C.H.; CARVALHO, J.E.U. 2003. Seleção de progênies de maracujazeiro-amarelo (Passiflora edulis f. flavicarpa) quanto à qualidade de frutos. Revista Brasileira de Fruticultura, 25(1):186-188.

NEGREIROS, J.R.D.S.; ARAÚJO NETO, S.E.D.; ÁLVARES, V.D.S.; LIMA, V.A.D.; OLIVEIRA, T.K.D. 2008. Caracterização de frutos de progênies de meios-irmãos de maracujazeiro-amarelo em Rio BrancoAcre. Revista Brasileira de Fruticultura, 30(2):431-437.

OLIVEIRA, E.J.; SOARES, T.L.; BARBOSA, C.J.; SANTOS-FILHOS, H.P.; JESUS, O.N. 2013. Severidade de doenças em maracujazeiro para identificação de fontes de resistência em condições de campo. Revista Brasileira de Fruticultura, 35:485-492.

OLIVEIRA, E.J.; VIEIRA, M.L.; GARCIA, A.A.F.; MUNHOZ, C.F.; MARGARIDO, G.R.A.; MATTA, P.; MORAES, M.M. 2008. An Integrated Molecular Map of Yellow Passion Fruit Based on Simultaneous Maximum-likelihood Estimation of Linkage and Linkage Phases. The Journal of the American Society for Horticultural Science, 133(1):35-41.

PAULA, M.S.; FONSECA, M.E.N.; BOITEUX, L.S.; PEIXOTO, J.R. 2010. Caracterização genética de espécies de passiflora por marcadores moleculares análogos a genes de resistência. Revista Brasileira de Fruticultura, 32(1):222-229.

PERDIZIO, V.A.; MACHADO, O.L.T.; ARAUJO, J.S.; OLIVEIRA, A.E.A.; MONTEIRO, L.R.; COSTA, M.N.; FERREIRA, A.T.; PERALES, J.; JACINTO, T.2015. Critical evaluation of proteomic protocols for passion fruit (Passiflora edulis Sims) leaves, a crop with juice market benefits. African Journal of Biotechnology, 19:1662-1667. 
PEREIRA, G.S.;NUNES, E.S.;LAPERUTA, L.C.; BRAGA, M.F.;PENHA, H.A.; DINIZ, A.L.;MUNHOZ, C.F.;GAZAFFI, R.; GARCIA,A.A.F.; VIEIRA, M.L.C. 2013. Molecular polymorphism and linkage analysis in sweet passion fruit, an outcrossing species. Annals of Applied Biology, 162(3):347-361.

PIMENTEL, L.D.; STENZEL, N.M.C.; CRUZ, C.D.; BRUCKNER, C.H. 2008. Seleção precoce de maracujazeiro pelo uso da correlação entre dados de produção mensal e anual. Pesquisa Agropecuária Brasileira, 43:1303-1309.

PREISIGKE, S.C.; MARTINI, F.V.; ROSSI, A.A.B.; SERAFIM, M.E.; BARELLI, M.A.A.; LUZ, P.B.; ARAUJO, K.L.; NEVES, L.G. 2015. Genetic variability of Passiflora spp. against collar rot disease. Australian Journal of Crop Science, 9(1):69-74.

RESENDE, M.D.V. 2002. Selegen-Reml/Blup - Seleção genética computadorizada: manual do usuário. Embrapa CNPF, Colombo. 67p.

ROCHA, M.G.B.; PIRES, I.E.; XAVIER, A.; CRUZ, C.D.; ROCHA, R.B. 2006. Genetic evaluation of half-sib Eucalyptus urophylla progenies by the REML/BLUP and minimum squares procedure. Ciência Florestal, 16(4):369-379.

ROSADO, L.D.S.; SANTOS, C.E.M.; BRUCKNER, C.H.; NUNES, E.S.; CRUZ, C.D. 2012. Simultaneous selection in progenies of yellow passion fruit using selection indices. Rrevista Ceres, 59(1):95-101.

RUGGIERO, C.; SÃO JOSE, A.R.; VOLPE C.A.; OLIVEIRA, J.C.; DURIGAN, J.F.; BAUMGARTNER, J.G.; SILVA, J.R.; MAKAMURA, K.I.; FERREIRA, M.E., KAVATI, R.; PEREIRA V.P. 1996. Maracujá para exportação: aspectos técnicos da produção. MAARA/SDR- FRUPEX Embrapa-SPI, Brasilia. $64 \mathrm{p}$.

SAMPAIO, A.C.; SCUDELLE, N.; FUMIS, T.F.; ALMEIDA, A.M.; PINOTTI, R.N.; GARCIA, M.J.M.; PALLAMIN, M.L. 2008. Manejo cultural do maracujazeiro amarelo em ciclo anual visando à convivência com o vírus do endurecimento dos frutos: um estudo de caso. Revista Brasileira de Fruticultura, 30:343-347.

SANTOS, C.E.M. BRUCKNER, C.H.; CRUZ, C.D.; SIQUEIRA, D. J.; PIMENTEL, L.D.; ROSADO, L.D.S. 2010. Repetibilidade em características do fruto do maracujazeiro. Revista Ceres, 57:343-350.

SANTOS, C.E.M. BRUCKNER, C.H.; CRUZ, C.D.; SIQUEIRA, D. J.; ROSADO, L.D.S. 2011. Componentes genéticos aditivos e não aditivos em maracujazeiro-azedo. Pesquisa Agropecuária Brasileira, 46:482-490.

SANTOS, E.A.; VIANA, A.P.; FREITAS, J.C.O.; SILVA, F.H.L.; RODRIGUES, R.; EIRAS, M.2015. Resistance to Cowpea aphid-borne mosaic virus in species and hybrids of Passiflora: advances for the control of the passion fruit woodiness disease in Brazil. European Journal of Plant Pathology, 2:1-14.

SCHLÖTTERER, C. 2004. The evolution of molecular markers - just a matter of fashion? Nature Reviews Genetics, 5:63-69.

SCHULMAN, A.H. 2007. Molecular markers to assess genetic diversity. Euphytica, 158:313-321.

SILVA, F. H. L.; MUÑOZ, P. R.; VINCENT, C. I.; VIANA, A. P. 2016. Generating relevant information for breeding Passiflora edulis: genetic parameters and population structure. Euphytica, 208:609-619.

SILVA, F.H.L.; VIANA, A. P.; FREITAS, J.C.DEO.; SANTOS, E.A.; RODRIGUES, D.L.; AMARAL JUNIOR, A. T. 2017. Prediction of genetic gains by selection indexes and REML/BLUP methodology in a population of sour passion fruit under recurrent selection. Acta Scientiarum.Agronomy, 39:183-190.

SILVA, F.H.L.; VIANA, A.P.; FERREIRA, R.T.; FREITAS, J.C.O.; SANTOS, J.O.; RODRIGUES, D.L. 2014. Measurement of genetic diversity in progenies of sour passion fruit by ward-mlm methodology: a strategy for heterotic group formation. Ciência e Agrotecnologia, 38(3):240-246. 
SILVA, M.G.M.; VIANA, A.P.; GONÇALVES, G.M.; JÚNIOR, A.T.DOA.; PEREIRA, M.G. 2009. Seleção recorrente intrapopulacional no maracujazeiro amarelo: alternativa de capitalização de ganhos genéticos. Ciência e Agrotecnologia, 33(1):170-176.

SOLLER, M.; BECKMANN, J.S. 1983. Genetic polymorphism in varietal identification and genetic improvement. Theoretical and Applied Genetics, 67:25-33.

SUASSUNA, T.M.F.; BRUCKNER, C.H.; CARVALHO, C.R.; BORÉM, A. 2003. Self incompatibility in passionfruit: evidence of gametophytic-sporophytic control. Theoretical and Applied Genetics, 106:298-302.

TAHARA, S.T.; MEHTA, A.; ROSATO, Y.B. 2003. Proteins induced by Xanthomonas axonopodis pv. passiflorae with leaf extract of the host plant (Passiflorae edulis). Proteomics, 3(1):95-102.

TAUTZ, D.1989. Hypervariability of simple sequences as a general source for polymorphic DNA markers. Nucleic Acids Research, 17:6463-6471.

TEIXEIRA, D.H.L., OLIVEIRA, M.S.P., GONCALVES, F.M.A., NUNES, J.A.R. 2012. Selection index for simultaneously improving fruit production components of assai palm. Pesquisa Agropecuária Brasileira, 47(2):237-243.

VIANA, A. P.; PEREIRA, T. N. S.; PEREIRA, M. G.; AMARAL JR, A. T. DO; SOUZA, M. M.; MALDONADO, J. F. M. 2003. Diversidade genética entre genótipos comerciais de maracujazeiro-amarelo (P. edulis f. flavicarpa) e entre espécies de Passifloras nativas determinada por marcadores RAPD. Revista Brasileira de Fruticultura, 25(3):489-493.

VIANA, A. P.; SILVA, FERNANDO HIGINO DE LIMA; GLÓRIA, L.S.; RIBEIRO, R.M.; KRAUSE, WILLIAN; BOECHAT, M.S. 2017. Implementing genomic selection in sour passion fruit population. Euphytica, 213(10):1-13.

VIANA, A.P.; GONÇALVES, G.M. 2005. Genética quantitativa aplicada ao melhoramento genético do maracujazeiro. In: Faleiro, F.G.; Junqueira, N.T.V.; Braga, M.F. (Ed.). Maracujá: germoplasma e melhoramento genético. Embrapa Cerrados, Planaltina. p.243-274.

VIANA, A.P.; SILVA, F.H.L.; GONÇALVES, G.M.; SILVA, M.G.M.; FERREIRA, R.T.; PEREIRA, T.N.S.; PEREIRA, M.G.; AMARAL JÚNIOR, A.T.; CARVALHO, G.F. 2016. UENF Rio Dourado: a new passion fruit cultivar with high yield potential. Crop Breeding and Applied Biotechnology, $16: 250-253$.

VIANA, A.P.; SILVA, F.H.L.E.; SILVA, M.G.M.; FERREIRA, R.T. 2012. Melhoramento intrapopulacional do maracujazeiro amarelo assistido por procedimentos de seleção genômica ampla. In: XXII Congresso Brasileiro de Fruticultura. Embrapa, Bento Gonçalves. p.1-4.

VIEIRA, C. 1964. Curso de melhoramento de plantas. Impresso pela divisão de informação da Universidade Rural do Estado de Minas Gerais -UREMG, Viçosa. 294p.

VIVAS, M.; SILVEIRA, S.F.; VIANA, A.P.; AMARAL JUNIOR, A.T.; CARDOSO, D. L.; PEREIRA, M.G. 2014. Efficiency of circulant diallels via mixed models in the selection of papaya genotypes resistant to foliar fungal diseases. Genetics and Molecular Research, 13(3):4797-4804.

VOS, P.; HOGERS, R.; BLEEKER, M.; REIJANS, M.; VAN DE LEE, T.; HORNES, M.; FRIJTERS, A.; POT, J.; PELEMAN, J.; KUIPER, M.; ZABEAU, M. 1995. AFLP: A new technique for DNA fingerprinting. Nucleic Acids Research, 23:4407-4414.

WILLIAMS, J.G.; KUBELIK, A.R.; LIVAK, K.J.; RAFALSKI, J.A.; TINGEY, S.V. 1990. DNA polymorphisms amplified by arbitrary primers are useful as genetic markers. Nucleic Acids Research, 18:6531-6535.

ZIETKIEWICZ, E.; RAFALSKI, A.; LABUDA, D. 1994. Genome fingerprinting by simple sequence repeat (SSR)-anchored polymerase chain reaction amplification. Genomics, 20:176-183. 